14

\title{
Spiritual writings and religious instruction
}

\begin{abstract}
ALEXAN DRA BARRAT'T
As soon as a would-be writer picked up the pen in this period, he (or just occasionally she) had to make a far-reaching decision: whether to write in English, Anglo-Norman or Latin. The answer would emerge from the intersection of the text's genre and of the gender, social and religious status of both the writer and the planned audience. Until around 1300, Latin texts would be read almost exclusively by male clerics and vernacular texts by the laity of both sexes and by women religious, ${ }^{1}$ though Anglo-Norman texts might be aimed at a slightly higher social class than those in Middle English. But Latin texts mightalso function as scripts for oral transmission by priests to their parishioners in English, while male clerics did read, and own, texts in French and English as well as Latin. In the fourteenth century, however, 'a new, more pragmatic view of the appropriate language' developed. ${ }^{2}$ The choice of French or English became 'fundamentally a political decision - whether to address the rulers or the ruled. The writers themselves, nearly always clerics, are those with education who are for that reason part of the establishment of power. In composing in English they are addressing the unlearned, sometimes to edify, sometimes to entertain, always to instruct.' ${ }^{3}$ Texts presuppose competent readers, so we must also consider the ability to read, especially among the laity:
\end{abstract}

The turning-point in the history of lay literacy came in the twelfth century. It is among the Anglo-Norman nobility that we find the first indications of a more extensive cultivated literacy... Prior to 1300 the language of theliterate laity was French, but during the course of the fourteenth century French ceased to be the principal vernacular in England and becamea more educated accomplishment. 4

But at the beginning of this period Latin was the dominant language of learned and literate religious discourse. Historians of the book quickly find

\footnotetext{
1 Itshould however be noted that manuscripts "belonging to individual women and to fernale communities in Anglo-Norman England include all the possible variations among the main languages .... all in French, all in Latin, all in English, bilingual and trilingual': Wogan-Browne 2001, p. 15. 2 Gillespie 1989, P. 318. 3 Turville-Petre 1988, p. 1. 4 Parkes 1973, pp. 556, 564-5.
} 
themselves adrift in a vast sea of Latin manuscripts, of works of religious instruction, devotion and contemplation, ranging from the elementary and catechetical, to the sublime and contemplative. We can but cast our net, in hope and faith, into the teeming waters and, commenting selectively on the catch, throw much of it back.

The relationship between the intended audience and the demonstrable readership and/or ownership of texts is notalways predictable, as one 'mystical' text, containing ascetic teaching and affective meditation, demonstrates. Aelred's brief letter to his recluse sister, De institutis inclusarum (c.1160), is found with other didactic and mystical texts: for instance, Bodleian, ms. Bodley 36 , contains Grosseteste's Templum Dei and Raymond of Peñafort as well as mystical texts by the Victorines, Anselm of Canterbury and Bernard of Clairvaux. In the fifteenth century it belonged to the Carmarthen Franciscans. Of other extant manuscripts, part of BL, Cotton ms. Nero A. III (13 th c.) belonged to Witham Charterhouse; Bodleian, ms. Digby 218 (13 th/14th c.) to Merton College; Paris, Bibliothèque de l'Université, ms. 790 (dated 1373) to the Cistercian abbey at Whalley; Hereford, Cathedral Library, ms. p. I. 17 (12th/13th c.) to the Augustinian canons at Cirencester; Bodleian, ms. Hatton 101 (13 th c.) to the Cistercians at Holme Cultram; BL, Royal ms. 8 D. III to the Benedictine house at Ramsey, Hunts. 5 The text also appears in medieval catalogues and inventories: the Cistercian houses at Meaux (1396 inventory) and Rievaulx (1st catalogue of c.1190-1200) held copies, ${ }^{6}$ as did the Benedictines of Ramsey and Winchcombe (extracts), ${ }^{7}$ and the York Augustinian Friars (extracts). ${ }^{8}$ But not one belonged to a woman or a women's religious house, even though the text is very obviously addressed to a woman. ${ }^{9}$ To reach the equivalent of its original audience in the later Middle Ages, the text had to be translated into the vernacular: one of the two Middle English versions is found in the Vernon manuscript (Bodleian, ms. Eng. poet. a. 1: see further below), which may have been compiled for a group of women. ${ }^{10}$

Edmund of Abingdon's Speculum ecclesie (early 13th c), 'indisputably a seminal text in the development of mediaeval English mysticism', ${ }^{11}$ combines teaching on contemplative prayer with religious instruction even more basic than Aelred's. The original Latin version, written for a single male religious, possibly a Cistercian, survives in Bodleian, ms. Hatton 26 (see further

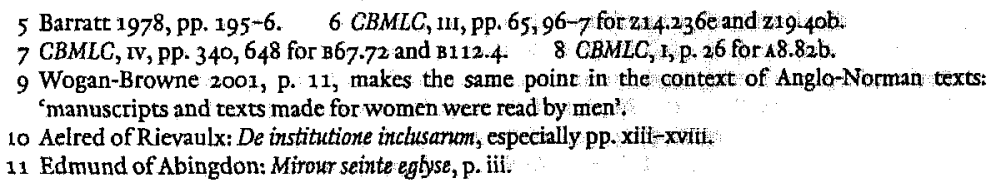


below). On three separate occasions it was translated back into Latin from the Anglo-Norman versions (one probably made for women religious, one for lay people): altogether thirty-six manuscripts of the various Latin versions survive. ${ }^{12}$ The Dover Benedictines owned two copies, while a thirteenth-century book-list from Gloucester Abbey lists a Speculum ecclesie, probably Edmund's and probably in Latin. ${ }^{13}$ Moreover, St Augustine's Abbey, Canterbury, was given a volume including 'speculum Edmundi Archiepiscopi Cantuariensis' by Michael de Northgate (fl. 1340, author of the Ayenbite of inwyt), while in 1394 John Hopton, chantry chaplain, bequeathed 'a book called Speculum ecclesiaes to the chantry of St Nicholas, Holy Trinity, Goodramgate, York. ${ }^{14}$

Edmund's Speculum probably predates 1215 , but Latin works of religious instruction in this period cannot be discussed without reference to the seismic impact of the Fourth Lateran Council, held in that year. Its decree Omnis utriusque sexus heralded a new emphasis on the sacrament of penance and consequently on clerical and lay religious education, ${ }^{15}$ and threw up a vast new genre, pastoralia, a term which 'embraces any and every literary aid or manual which may be of help to a priest in his cura animarum, whether with respect to his own education or that of the people in his charge'. ${ }^{16}$ These texts are of cardinal importance, and not least from the perspective of the history of the book. Their wide ownership is well documented, while they used 'new techniques for presenting information', such as alphabetical organization, the distinctio (sometimes set out schematically) and didactic verses, to convey information concisely and memorably. ${ }^{17}$ Although the most popular and influential were the summae of the Spaniard Raymond of Peñafort and the Frenchman Gullielmus Peraldus, Britain produced its own variants and it is on these that we shall concentrate.

One of the earliest (c.1215-20) was the Qui bene presunt of Richard of Wetheringsett. ${ }^{18}$ Copies (often more than one) were widely owned by various religious houses: the Premonstratensians of Bradsole and the Cistercians of Meaux (two copies); ${ }^{19}$ the Benedictines of Gloucester (thirteenth-century

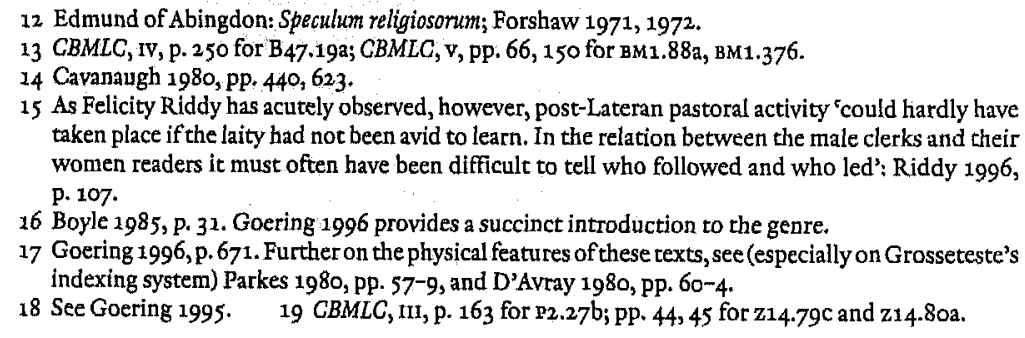


list), of St Benets Holme (Leland's list), of Ramsey (two copies, midfourteenth-century lists), of Rochester Cathedral Priory (1346 gift by Bishop Hamo); of St Albans Abbey (early fifteenth-century list) and of Dover Priory (six copies). ${ }^{20}$ The Augustinian canons of Lanthony (Gloucester) owned Lambeth, mss. 392 pt. 2 and 398 pt. ${ }^{2 .}{ }^{21}$ Thomas of Cirencester, monk of St Augustine's, Canterbury ( $f$. 1287), gave his abbey a copy. ${ }^{22}$ It is interesting that no friars' library is recorded as holding this text, but their book-holdings are generally less well documented than are those of other possessors.

Thomas of Chobham's Summa confessorum, ${ }^{23}$ 'one of the fullest and most interesting pastoral summae, ${ }^{24}$ was also early, completed by c.1216. The Premonstratensians of Bradsole (in the late thirteenth century) and of Titchfield owned copies, ${ }^{25}$ as did the Benedictines of Evesham, Norwich (Yarmouth), St Mary's, York (no fewer than thirteen copies), and Dover (two copies). ${ }^{26}$ From the mid-fourteenth century we have information about copies in private clerical ownership. In an inventory of books sold to pay his debt to Queen Isabella, the royal civil servant William de Walcote $(f l .1349$ ) lists ' j. livre de Chabham' twice, while in 1413 William Cave, rector of Woodchurch, Kent, bequeathed a copy. ${ }^{27}$

Pastoralia came, literally, in all shapes and sizes. Robert Grosseteste, Bishop of Lincoln (c.1170-1253), composed his Templum Dei, ${ }^{28}$ 'a popular confessional manual ... which survives in over go Latin MSS, between 1220 and $1230 .{ }^{29}$ Leonard Boyle ascribed its popularity to its mnemonic quality: $3^{\circ}$ it is extremely brief and usually comes complete with ingenious diagrams that visually summarize its basic catechetical teaching. Copies were owned by the Cistercians of Fountains (Leland's list) and of Meaux (two copies) $3^{31}$ by the Benedictines of Gloucester (thirteenth-century list), of Ramsey (three copies in the midfourteenth-century catalogue) and of Reading (1253 account of a stolen book, possibly now Bodleian, ms. Auct. D. 4. 10). $3^{2}$ The Augustinian friars of York and the Carmelites of Hulne owned copies ${ }^{33}$ and the Lanthony Augustinian

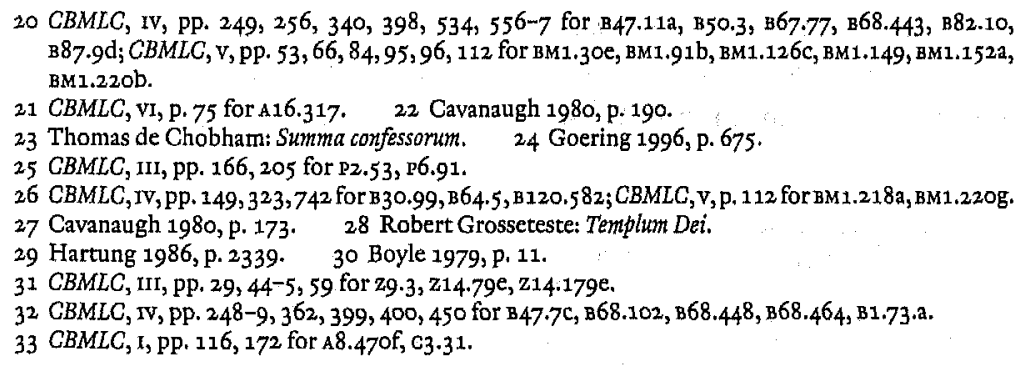


canons (regular clergy with a pastoral vocation) owned four. ${ }^{34}$ It was clearly the kind of text that religious houses held in multiple copies - 'class sets', as it were. Secular priests, too, would find it useful: in 1439 William Pyers, rector of Sandhurst, Kent, and dean of the collegiate church of South Malling, Sussex, bequeathed his church a copy. 35

One of the most widely owned, and best documented, Latin works of religious instruction was William of Pagula's Oculus sacerdotis (consisting of the Pars oculi, the Dextera pars and the Sinistra pars,,${ }^{36}$ which 'approach[es] pastoral care from the three angles of confessional practice, sacramental theology and preaching matter'. ${ }^{37}$ William also wrote the Summa summarum, a compilation of canon law and theology (written 'ad profectum et utilitatem

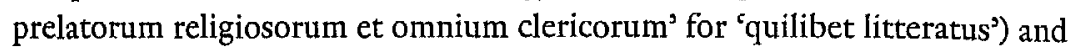
the Speculum prelatorum (incorporating James of Milan's Stimulus amoris). The Oculus was written between 1320 and $13^{26}$, for 'ill-educated parish priests'; $3^{8}$ but copies were owned by clerics of all conditions - cathedral clergy, parish priests, religious and secular. Of surviving copies, Norwich Cathedral Priory owned CUL, ms. Ii. 2. 7 (fourteenth-century), Canterbury Cathedral Priory owned Canterbury Cathedral Library ms. D. 8 (fourteenth-century), the parish church at Halsall (Lancs) owned Manchester John Rylands Library, ms. lat. 339 (late fourteenth-century), Worcester Cathedral Priory owned Bodleian, mss Bodley 828 (late fourteenth to fifteenth-century) and Hatton 11 (1404?).39 The house of Bonshommes at Ashridge, Buckinghamshire (who followed the Augustinian Rule and were presumably involved in pastoral work), owned both Oxford, Trinity College, ms. 18 (thirteenth and fourteenth-century), heavily annotated and corrected, and San Marino CA, Huntington Library, ms. EL 9 H. 3 (late fourteenth-century). ${ }^{\circ}$ Exeter Cathedral owned Bodleian, ms. Bodley 293 (fourteenth-century) and Reading Abbey the very large $(445 \times 300 \mathrm{~mm}) \mathrm{BL}$, Royal ms. 1o D. X (late fourteenth-century), designed as a reference book or for public reading. ${ }^{41}$

The Titchfield Premonstratensians owned a copy of the Pars oculi; c.1400 the vicar of Swine donated a copy to the local Cistercian nuns; the London Cistercians owned a Speculum religiosorum (part of the Speculum prelatorum). ${ }^{42}$ The Eynsham Benedictines owned a Summa summarum (catalogue of $1363 \times$ 1366 ), as did their brothers of Glastonbury (catalogue of 1247/48), Norwich

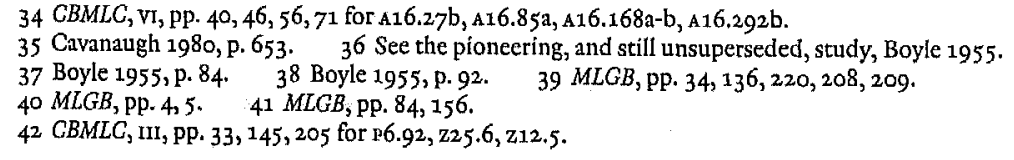


(Yarmouth cell), and St Albans (early fifteenth-century catalogue, copy given by Thomas Rysborowhe, prior c.1349) (they also owned an Oculus), while StMary's, York, had five copies of the Oculus and two of the Summa summarum. 43 The York Augustinian friars had a copy of each. ${ }^{44}$ The Augustinian canons of Lanthony had one, ${ }^{45}$ while the Dover Benedictines owned two copies of the Pars oculi and two of the Summa summarum. ${ }^{6}$

We have also extensive evidence of ownership from medieval wills and inventories. Cavanaugh lists sixteen gifts or bequests of the Oculus between $133^{\circ}$ and 1400 , often to parish churches. For instance, in 1382, Thomas de Lexham, canon of Hereford, bequeathed a copy to the church of Feltwell St Mary, Norfolk, 'to be chained to the desk on the right hand side of the choir where the rector sits'.47 Copies also appear in inventories of c. 1349 and 1369 , while the 1368 registry of church goods of the Norwich archdeaconry details no fewer than eleven..$^{8}$ There were also bequests of the rarer and more specialized Summa summarum in 1369, 1393 and 1395 (appropriately to Thomas Arundel, Archbishop of York), ${ }^{49}$ and copies appear in inventories of 1369 and $1386 . .^{\circ 0}$ If our investigations are extended into the first decades of the fifteenth century, we find a copy of the Pars oculi bequeathed by a draper. ${ }^{51}$

Vernacular texts, although less common than Latin, have attracted far more attention. Ancrene wisse, ${ }^{52}$ the early thirteenth-century Middle English guide for anchoresses, is 'essentially a work of practical religious instruction', ${ }^{53}$ and should be seen in the same intellectual context as the Latin works. ${ }^{54}$ But it was a markedly more mobile text, not only in terms of language. A distinction must be made between its original and subsequent audiences: although it was initially composed for three female recluses, Watson suggests that even then it had 'two subsidiary audiences (the author's learned colleagues and the anchoresses' perhaps illiterate servants)'.55 In the twelfth and thirteenth centuries such anchoresses, technically lay women, 'seem to have been significant for the development of vernacular literature mainly because of their intermediate position between laici and clerici, illiterates and literati'.$^{56}$ Watson similarly sees this original audience as drawn from a "new cadre of "semi-educated"

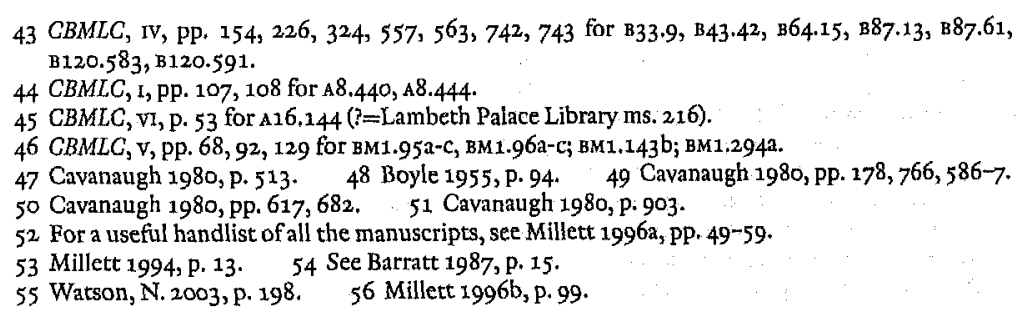


contemplatives ... defined less by lack of Latinity than by lack of a guarantee of Latinity'. ${ }^{57}$ But the text was early adapted for a larger group of women and 'later reworked for nuns, for male religious, for a mixed general audience including both religious and laity, and for a lay audience..$^{8}$ This is reflected in what little we know of the ownership of the various copies, and what we can deduce from their physical appearance.

BL, Cotton ms. Nero A. XIV (c.1225-50), contains a copy of the Middle English version of Ancrene wisse addressed to the original three sisters, together with other texts such as the Marian prayer, On lovsong of ure lefai (fig. 14.1). The smallest of all the English and French manuscripts $(144 \times 107 \mathrm{~mm})$, it was probably designed for individual reading and study. The ornamentation is simple and its editor comments on its general economy. ${ }^{59}$ Its near contemporary, BL, Cotton ms. Titus D. XVIII, is very little larger $(157 \times 120 \mathrm{~mm})$. This version betrays 'relatively superficial if unsystematic revisions for a male audience, ${ }^{30}$ But the manuscript's other texts (Sawles ward, Hali meiðhad, Wohunge of ure Lauerd and Seint Katerine) suggest a specifically female audience and together constitute a 'one-volume library' of the Ancrene wisse group, a 'highly intelligentselection and ordering of the principal anchoritic works'. ${ }^{61}$

BL, Cotton ms. Cleopatra C. VI (dated by its editor C.1227-8), contains a transitional version of Ancrene wisse. E. J. Dobson originally suggested that the principal scribe was herself an anchoress, 'industrious and devoted, but neither well trained nor very quick of understanding ${ }^{3}{ }^{62}$ He later abandoned this theory, ${ }^{63}$ and the scribe acquired a "clear, firm, and bold hand. ${ }^{64}$ Scribe $\mathrm{B}$, the corrector and reviser, Dobson argued, was the author of Ancrene wisse himself. The manuscript, though plain, seems not to have been designed with economy in mind: it has spacious margins, either for aesthetic reasons or for annotation and revision. Matilda de Clare, Countess of Gloucester (d. 1289), gave it to the Augustinian canonesses of Canonsleigh Abbey, which she had founded. Cambridge, Corpus Christi College, ms. 402 (c.1225-50), contains a revision by the original author for an expanding community. Larger than the other early manuscripts $(215 \times 148 \mathrm{~mm})$, with its dark, clear black ink, it would be a good size for communal reading. ${ }^{65}$ Around 1300 John Purcel gave it

\footnotetext{
57 Watson, N. 2003, p. $200 . \quad 58$ Millet 1994, p. 14. 59 English Ancrene riwle 1952, p. xvi. 60 Dahood 1997, p.9. 61 Anchoritic spirituality, p. 29. 62 Dobson 1962, p. 163.

63 English Ancrene riwle 1972, p. lvi, fn. 2. 64 English Antcrene riwle 1972, p. xlvi.

65 English Ancrente riwle 1962. On the physical appearance of the Corpus manuscript see Dahood 1988. He concludes that "in the earliest extant manuscripts... Ancrene Riwle was in some measure set out as a study text. Whoever first imposed the system of graduated inirials was concerned that readers grasp the relationships between divisions and not just focus on discrete passages. This concern is compatible with the author's express concern, evident from the lexical cues in the text, to make the structure clear' (p. 97). See Parkes, chap. 6, p, 128 n. 102 for a s. xiii $4 / 4$ dating.
} 


\section{Spiritual writings and religious instruction}

to the Augustinian canons at Wigmore, ${ }^{66}$ possibly because its author had been a member of that community.

On the much reworked French version in Trinity College, Cambridge, ms. R.14.7 (late thirteenth/early fourteenth-century), see further below. Cambridge, Gonville and Caius College, ms. 234/120 (mid or late thirteenthcentury), is small ( $135 \times 95 \mathrm{~mm})$, modest and not obviously user-friendly. It contains an English version of Ancrene wisse as well as extracts from the Vitas patrum in Latin, which suggests that the compiler, or the owner, had eremitic interests and was probably male. BL, Cotton ms. Vitellius F. VII (early fourteenth-century), contains a late copy of an earlier Anglo-Norman version, ${ }^{67}$ which was a close translation of Ancrene wisse ${ }^{68}$ Badly damaged in the Cotton fire, the manuscript was obviously once a handsome volume, more so than 'first generation' copies of the English text, which perhaps reflects the higher social status of Anglo-Norman. A compilation of ascetic and pastoral as well as contemplative and anchoretic material, it also contains a treatise on the pains of purgatory and hell and the joys of heaven, the Livre de tribulacion, ${ }^{69}$ and 'diuerses oreisouns et meditaciouns ${ }^{9} .7^{\circ}$ Some time between 1433 and 1441 Joan, Countess of Kent, gave the volume to Eleanor Cobham, wife of Humfrey, Duke of Gloucester: $7^{71}$ Jocelyn Wogan-Browne has rightly stressed that Ancrene wisse is 'a text with a significant Anglo-Norman career, and a text that was still being exchanged in French by women in fifteenth-century England'.$^{2}$

The fourteenth century saw further changes in audience. Watson comments that Nicholas Love, The chastising of God's children and Walter Hilton all treat Ancrene wisse as a 'specialized guide for professional religious or semireligious' ${ }^{33}$ while other fourteenth- and fifteenth-century works see it as for serious-minded lay people who have inherited the semi-religious status of the original anchoresses. Gillespie points out that 'Five surviving copies ... . were made in the fourteenth century. Adaptations in two of the manuscripts point towards audiences far beyond the anchoresses for whom it was originally composed'.74 One of these is Oxford, Merton College, ms. 44 (first half of the fourteenth century) which contains a Latin version of Ancrene wisse (omitting Book 8), along with such pastoralia as Grosseteste's Templum Dei and Raymond of Peñafort. Another is Cambridge, Magdalene College, Pepys ms. 2498 (c.1350-1400), which contains an English version: far too unwieldy $(340 \times 240 \mathrm{~mm})$ for private devotional reading, it must have belonged to a

\footnotetext{
66 English Ancrene riwle 1962, pp. xvii-xviii. $\quad 67$ Wogan-Browne 2001, p. 13 n. 20 68 Dean and Boulton, 1999 , no. 643 . 69 See Book of tribulation, pp, $18 \rightarrow 22$.

70 Dean and Boulton 1999, nos. 646,648,942. 71 See French Ancrene riwle 1944, pp: xi-xiii. 72 Wogan-Browne 2001, p. 13. 73 Watson, N. 2003, p. 204. : 74 Gillespie 1989, p. 321.
} 
community. With its large red and blue initials and red underlining for Latin quotations, it is easily the grandest of the Ancrene wisse manuscripts apart from Vernon. Watson comments on 'the visual care of its manuscript presentation' and points out that this version, which is addressed to both men and women, 'remarkably rethinks the entirety of Ancrene wisse as a rule for the laity' or 'a rule for all Christians' ${ }^{75}$ Finally, there is a 'modernized'version of Ancrene wisse, by a scribe who 'followed an innovating tendency' ${ }^{76}$ in the late fourteenth-century Vernon Manuscript (discussed further below).

There is only one known mention of Ancrene wisse in a will. John Clifford, mason, of Southwark, London, bequeathed to the Franciscan nuns at Aldgate

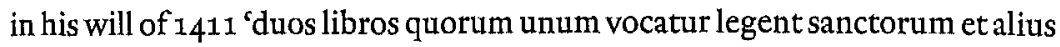
recti diligunt te': 77 the latter incipit is that of Ancrene wisse. This is interesting evidence of lay ownership of this text - and of its eventual re-integration into a regular religious community.

Of the other texts associated with Ancrene wisse, Hali meiðhad, apparently composed for an audience of young women, potential recruits to the anchoritic life but not yet vowed to virginity, is found, along with Sawles Ward and Seint Katerine, in BL, Cotton ms. Titus D. XVIII (see above), and also in Bodleian, ms. Bodley 34 (c.1200-25). The latter is a small, compact book, much the same size as BL, Cotton ms. Nero A. XIV (118 $\times 77 \mathrm{~mm})$, written in a 'glossing hand' with red initials at beginnings of each text. We have no information on early ownership.

Perhaps surprisingly, the first relevant Anglo-Norman text of religious instruction is somewhat later than the earliest versions of Ancrene wisse. Corset $7^{8}$ a rhymed commentary on the seven sacraments, was written c.1240-50 by Robert of Greatham, 'le Chapelain', possibly an Augustinian canon from Lilleshall (Northants), for 'seignor Alain' (line 1). The poet thanks God, master of all knowledge,

Ki vostre halt sen tant encline

Que vous avez escun divine.

[divinity lesson]

Et quant n'entendez la letrure,

[learning i.e. Latin]

Al franceis oÿre metez cure ....

(lines 7-10)

75 Watson, N. 2003 , pp. 217, 219. See also Colledge 1939, arguing for a Lollard author. 76 English Ancrene rivile 2000. See also Diensberg 1997, p. 11. 77 Cavanaugh 1980, p. 197. $\quad 78$ Dean and Boulton 1999, no. 590 . 
The approach to the subject matter is fairly technical and contains a great deal on marriage but even more on the seven orders of priesthood. 79

The only copy is found in Bodleian, ms. Douce 210 (c.1300), which also contains the Mirour, an Anglo-Norman version of Edmund of Abingdon'sSpeculum, and other religious and moral pieces. Written in brown ink with no decoration, two columns to the page, some of its leaves are irregularly shaped, suggesting that it was compiled with economy in mind. It contains several French poems that would appeal to a secular audience with serious moral and philosophical interests: the unique copy of a verse treatise on knighthood, 'Le chevalier de Dieu', 80 'La petite philosophie'; 'Le roman de Fortune' (an adaptation of Boethius' Consolatio by Simon du Fresne (Simund de Freine), canon of Hereford); Gawain against marriage (an obviously clerical text) and 'Urban le courtois, ${ }^{31}$ a courtesy book for boys and young men. This looks like the kind of volume that a tutor in a noble household of boys and youths might use for educational and recreational purposes. ${ }^{82}$

Edmund of Abingdon's early thirteenth-century Speculum ecclesie was translated into Anglo-Norman as the Mirour de seinte eglyse. ${ }^{83}$ Twenty-seven full or partial manuscripts survive: at least four belonged to houses of male religious. Oxford, St John's College, ms. 190 (late thirteenth-century) is a spiritual compendium, its texts ranging from canon law to mysticism, via sermons and works of religious instruction. The Mirour is its only vernacular text, apart from a brief prose meditation. Written in tiny hands, so not designed for public reading, it belonged to Westminster Abbey. Oxford, Corpus Christi College, ms. 36 (early fourteenth-century) belonged to the priory of Augustinian canons at Lanthony, Gloucester. Cambridge, Trinity College, ms. 0. 1.17, belonged to the Cistercian abbey of Whalley; the (incomplete) Mirour is its final item. Lambeth, ms. 522 (late thirteenth-century), which contains numerous other religious and devotional pieces in prose and verse, belonged to St Augustine's Abbey, Canterbury (see further below). We also know that Solomon de Ripple (fl. 1340) gave the same abbey a 'Speculum sancti Edmundi Archiepiscopi Cantuar', ${ }^{84}$ probably in French. Benedictine houses owning copies in the Middle Ages were Canterbury Cathedral Priory, ${ }^{85}$ Dover (two copies) ${ }_{2}^{86}$ Peterborough ${ }_{9}^{87}$ and St Augustine's, Canterbury. ${ }^{88}$ The Premonstratensians of Titchfield owned three copies, according to their catalogue of $1400 .{ }^{89}$

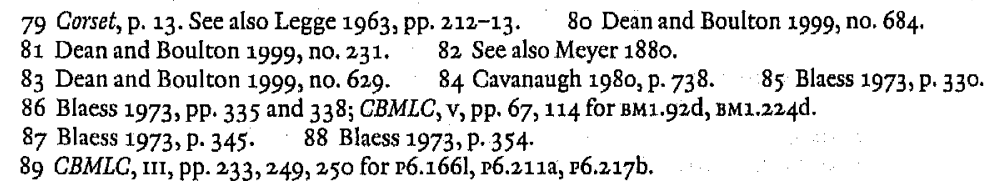


At least one surviving copy, however, belonged to religious women. Cambridge, Fitzwilliam Museum ms. McClean 123 (late thirteenth-century), which contains fragments only, belonged to the house of the order of Fontevrault nuns at Nuneaton. Its generous dimensions and bold black script suggest that it was designed for communal use. It contains ownership inscriptions of Alicia Scheyntoun and, significantly, 'domine Margarete Sylemon et discipulas suas'. Was Dame Margaret therefore the priory's magistra? The texts are mainly French, including an illustrated verse Apocalypse; $;^{\circ 0}$ at the end is a copy of the early Middle English Poema morale, a 200-line sapiential text.

Some copies of the Mirour were probably in secular ownership. One is Bodleian, ms. Douce 210 (see above); another is CUL, ms. Gg. 1.1 (first half of the fourteenth century, post-1308), which has an unusual format - small but more than six inches thick ( 633 leaves) - that suggests private study rather than public reading. It contains a large collection of French poetry, including the Lumere as lais (fig. 14.3) and the Manuel des pechés, Walter of Bibbesworth's treatise on learning French (addressed to a woman) interlined with English glosses, ${ }^{91}$ some Middle English verse (the Proverbs of Hendyng with an emphasis on child-rearing), a French Apocalypse with fifty-five illuminations, and an illustrated Image du monde. Its combination of prophecies, prognostications, history and popular science as well as biblical and devotional material suggests secular ownership. Possibly it belonged to an upwardly mobile, bilingual, gentry family.

Robert Grosseteste (c.1170-1253), Bishop of Lincoln and author of the Templum Dei, wrote an allegorical poem in Anglo-Norman, the Chasteau d'amour, ${ }^{92}$ 'for the instruction of the laity generally, but immediately and specifically, perhaps... for the noble youths... in his episcopal household' ${ }^{3}{ }^{93}$ The poet explains that notall can know Greek, Hebrew or Latin, but they are still obliged to praise their Creator. Therefore he has written in French for the unlearned:

$$
\begin{aligned}
& \text { En romanz comenz ma reson } \\
& \text { Pur ceus ki se sevent mire } \\
& \text { Ne lettreüre ne clergie. } \\
& \text { (lines 26-8)94 }
\end{aligned}
$$

There are eighteen complete or partial extant manuscripts, 'all but one from the last half of the thirteenth or the first half of the fourteenth century'. 95 Of these, Lambeth, ms. 522 (late thirteenth-century), which also contains the Mirour,

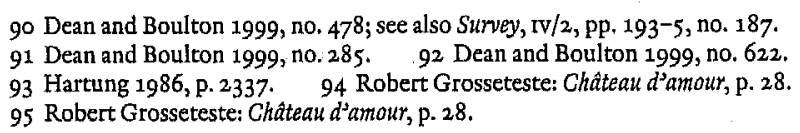


as has already been noted belonged to St Augustine's Abbey, Canterbury. It is a large book with large script, suitable for public or communal reading, with numerous pictures. The illustration on $\mathrm{f}$. I shows a bishop addressing an audience of laypeople, mainly women (fig. 14.2), though later illustrations show black monks and a few friars. A long note in Latin on $f$. iii $^{v}$ explains its use of French to cater for the laity: 'Et quamvis lingua Romana coram clericis suauitatem non habeat, tamen laicis qui minus intelligunt opusculum istud aptum est.' Possibly the Benedictine house held the manuscript on behalf of the laity. The Chasteau is also found in the Nuneaton Book, Cambridge, Fitzwilliam Museum, McClean ms. 123, with a fifteen-line Latin summary in red, and, together with the Mirour and Manuel des péchés, in $\mathrm{BL}$, Royal ms. 20 B. XIV (see further below).

Medieval catalogues show copies owned by both monks and mendicants. The Meaux Cistercians listed one in their 1396 inventory; ${ }^{96}$ the Premonstratensians at Titchfield owned three, at least one in Anglo-Norman.97 Canterbury Cathedral Priory, ${ }^{98}$ the Benedictine house at Peterborough ${ }^{99}$ and the London Carmelites owned a copy each, ${ }^{100}$ as did St Paul's Cathedral, and the Augustinian canons at Leicester. ${ }^{101}$

La lumere as lais, ${ }^{102}$ a lengthy (nearly 14,000 lines) versified work of religious instruction, was completed by the Augustinian canon Peter (or Pierre) of Pecham (or Fetcham) in $1267 .{ }^{103}$ Divided into books, chapters and distinctiones, the poem has a scholastic prologue, for Peter 'avait les habitudes de l'école et les a transportées dans son ouvrage'. ${ }^{104}$ He announces:

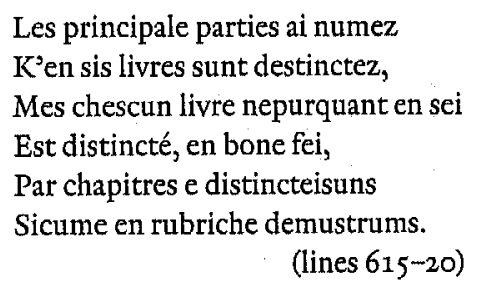

The manuscripts mainly preserve this system of text-division, as well as indicating the question-and-answer format with ' $m$ (agister)' and ' $\mathrm{d}$ (iscipulus)' in the margin as appropriate.

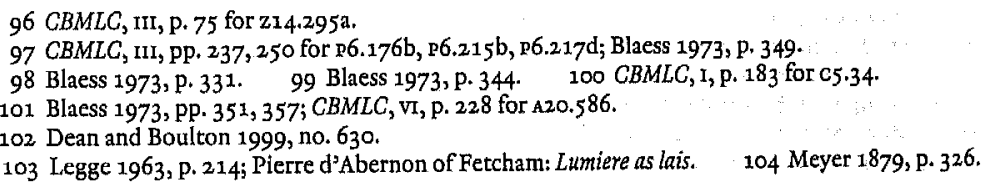


Peter describes himself as 'un clerc sui de petit renun,/De poi value, veraiment' (lines 544-5) and makes no attempt to adapt either his manner or his matter to an unlearned audience. Indeed, Arnould criticizes him as one of those who 'se croient encore sur les bancs de l'Université et ne réussissent à produire que des traductions, compilations ou adaptations pédantes' ${ }^{105}$ This is unnecessarily harsh: Peter claims to write primarily for lay folk who are intelligent enough but simply do not understand Latin:

$$
\begin{aligned}
& \text {... pur ceo ke franceis est entendable } \\
& \text { A lais, pur ceo l'ai numé, sanz fable, } \\
& \text { La 'Lumere as Lais' .... } \\
& \text { (lines 685-7) }
\end{aligned}
$$

His work is not for madmen or children (lines 695-8), though later he envisages an audience of 'Veuz e jufnes, femme[s] e enfanz'(line 13,954): Meyer describes it as representing the type of work 'composée pour des seigneurs normands ou plutôt pour leur femmes'. ${ }^{106}$

There are twenty-one complete or partial surviving manuscripts. One belonged to a noble family, one to a Gilbertine convent and one to a house of Cistercian nuns. Cambridge St John's College, ms. 167 (F. 3O), which also contains the Manuel des péchés, belonged to John Strelley 'de Lyndeby' in the fifteenth century; York, Cathedral Chapter Library, ms. xvI. N. 3, is the only manuscript to survive from the Gilbertine priory at Shouldham, Norfolk: ${ }^{107}$ it also contains a French version of Cato's Distichs and a political satire. Dublin, Trinity College, ms. B. 5.1 (209), belonged to Dame Joanna Kyngeston, Cistercian abbess of Tarrant Keynston (Dorset), in the fourteenth century. ${ }^{108}$ BL, Royal ms. 20 B. XIV, which also contains the Manuel des péchés and the Chasteau d'amour, belonged to John Colyford in 1361, and later to the soldier-diplomat Lord Walter Hungerford (1368-1449), Steward of the Household to both Henry V and Henry VI. ${ }^{109}$

BL, Royal ms. 15 D. II, which also contains an illustrated Apocalypse, extremely large $(445 \times 300 \mathrm{~mm})$ and lavishly though gaudily illustrated with historiated initials and borders, is a 'sumptuous specimen of East Anglian art... with text of a size suitable for a lectern'. ${ }^{110}$ It was probably executed for a wealthy lay person, a member of the Welles family, in the early fourteenth

105 Arnould 1940, p. 35

106 Meyer 1879, p. 325. See also DMOL, I, pp. $15^{-6}$ (Item 83) and Ix, Plate 146, for Bodleian, ms. Bodley 399, dated 1300 .

107 MLGB Suppl., p. 62; see also Manuscripts English polyphony, pp, xili-xv.

108 MLGB, p. 187; see also Cavanaugh 1980, p. 486 . 109 Cavanaugh 1980, pp. 203, $452-3$. 110 Legge 1963, p. 216 ; see also Survey, v/ 1 , pls. 75 and 79 , and Survey, v/2, pp. $39-40$, no. 34 . 
century. ${ }^{111}$ Bodleian, ms. Bodley 399 , written in 1300 , which also contains the Chasteau d'amour, is a user-friendly manuscript, carefully and clearly written, with few abbreviations, a comprehensive and detailed index, and running heads. Physically it is rather similar to Cambridge, St John's College, ms. 167 . Another manuscript mentioned earlier as probably in secular ownership, CUL, ms. Gg. 1.1 (first half fourteenth century), also contains the Lumere (fig. 14.3).

The Lumere occurs frequently in medieval wills and catalogues. In 1306 Guy of Warwick donated a copy to the Cistercian house at Bordesley (Worcs); ${ }^{112}$ in the late fourteenth century the Benedictine John Bradgar $(f l .1385)$ gave a copy to St Augustine's, Canterbury; ${ }^{113}$ between $135^{2}$ and 1392 Prior Nicholas of Hereford donated a copy to Evesham: $;^{114}$ c.1390 John de Brymmesgrave, sacrist of Evesham, gave his Benedictine abbey another. ${ }^{115}$. In his will of 1412 Richard Snetisham, fellow of Oriel College, Oxford, bequeathed a copy to his chaplain. ${ }^{116}$ The Augustinian canons at Leicester owned two ${ }^{117}$ and those at Lanthony one, bequeathed by John Leche, chancellor of Oxford, c.1355-60..$^{118}$ For a vernacular text, it therefore enjoyed surprisingly heavy male monastic ownership, perhaps because of its uncompromisingly scholastic and academic appearance. $^{119}$

The Manuel des péchés ${ }^{120}$ was composed in Lincolnshire between 1250 and 1275 by William of Waddington, a secular canon, servant of Walter Gray, Archbishop of York $1215^{-55},{ }^{121}$ ostensibly for the 'feble \& vaillant' (lines $35^{-}$ 6). The poem teaches 'the essentials of the Christian faith in the vernacular" ${ }^{122}$ to the laity. But it also 'became popular as a reference book for preachers' and was 'frequently treated as an encyclopedia for clerics, not as a manual for laymen'. ${ }^{123}$

There are twenty-eight surviving manuscripts, some only fragments. CUL, ms. Ee. 1. 20 (fourteenth-century) is user-friendly with running heads in the upper margin indicating content, and marginal notes (e.g. 'Sorcerie', 'karoles') locating topics. CUL, ms. Gg. 1.1 contains the Manuel as well as the Mirour. Cambridge, St John's College, ms. F. 30 (167) (see above), also contains the Manuel, though in a different hand from the Lumere and Mirour. John Colyford's book, BL, Royal ms. 20 B. XIV, contains the Maruel as well as the Mirour and the Chasteau. Its text has various finding aids, such as 'Cunte' (conte) and 'Ensample' (exemplum), written in the margin at appropriate points.

\footnotetext{
111 Egbert 1936, p. 448. $\quad 112$ CBMLC, mi, p. 9 for z2.24. 113 Cavanaugh 1980, p. 123. 114 CBMLC, rv, p. 15 o for 830.108 . 115 Cavanaugh 1980, p. 139 . 116 Cavanaugh 1980, p. 796 . 117 Blaess 1973, p. 357; CBMLC, vi, pp. $283,35^{8}$ for 220.924 and $\mathrm{A} 20.143^{\circ}$.

$118 C B M L C$, vi, p. 102 for A17.51. 119 Sec Legge 1963, pp. 214-16; Vising 1923, pp. 17, 57

120 Dean and Boulton 1999, no. 635. 121 Sullivan 1991, p. 155.

122 Shrifte and penante, p. 10. 123 Laird 1946, p. 259. See further Arnould 1940.
} 
The Manuel seems to have had wide appeal among male religious. The Cistercians at Meaux listed a copy in their 1396 inventory, ${ }^{124}$ as did the Titchfield Premonstratensians. ${ }^{125}$ Dover Priory owned one, ${ }^{126}$ as did the Augustinian canons at Leicester. ${ }^{127}$ St Augustine's, Canterbury, was given a copy by the monk Richard of Canterbury (fl. c. 1320). ${ }^{128} \mathrm{~A}$ parish priest's inventory of 1369 and a bequest of 1393 include our text. ${ }^{129}$ And in 1368 Simon Bredon, fellow ofMerton College, Oxford, left a copy to the Benedictine nuns at Malling (Kent). ${ }^{130}$ It is interesting that this text seems not to have appealed to the friars, in spite of their interest in the sacrament of penance.

Surviving manuscripts for which we have evidence of male clerical ownership include CUL, ms. Mm. 6.4 (fourteenth-century), which in the fifteenth century belonged to the Cistercian abbey of Quarr: the Manuel is its only French text. This copy lists the nine books with their subjects and writes the text as two octosyllabic couplets per line, indicating headings and text divisions with ' $\mathrm{Ci}$ comence . . ', also in red. BL, Harley ms. 273 , belonged to a parish church in Ludlow (Salop); $;^{131}$ BL, Harley ms. 4657 to Durham Cathedral Priory; ${ }^{132}$ BL, Harley ms. 4971, to Bury St Edmunds Abbey. ${ }^{133}$ Bodleian, ms. Greaves 51 (early fourteenth-century), contains the name 'Johannes de Prohun', ${ }^{134}$ who may have been a priest; York, Cathedral Chapter Library, ms. xvi. K. 7, belonged to a Canterbury Dominican friar; ${ }^{135}$ San Marino CA, Huntington Library, ms. HM 903, belonged to St Mary's Abbey, York, bought by or on behalf of brother Clement Warthwyk. ${ }^{136}$

In contrast, Princeton UL, Taylor Medieval ms. 1 (olim Phillipps ms. 2223), which also contains the Chasteau, is a 'late-thirteenth-century deluxe illustrated copy ... commissioned for a noblewoman'. ${ }^{137}$ It is 'easily carried in the hand, measuring $245 \times 125 \mathrm{~mm}$, but it is unusually narrow'.138 Heraldic devices indicate that it was made sometime between 1280 and 1298 for Joan Tateshal, daughter of Sir Ralph FitzRanulph (Yorks), who married Baron Robert Tateshal of Lincolnshire in $1268 .{ }^{139}$

Other Anglo-Norman treatises of religious instruction include the Franciscan John Pecham's Ierarchie, ${ }^{140}$ comparing the pseudo-Dionysian nine orders of angels to a king's household, which was written between 1279 and 1290 at

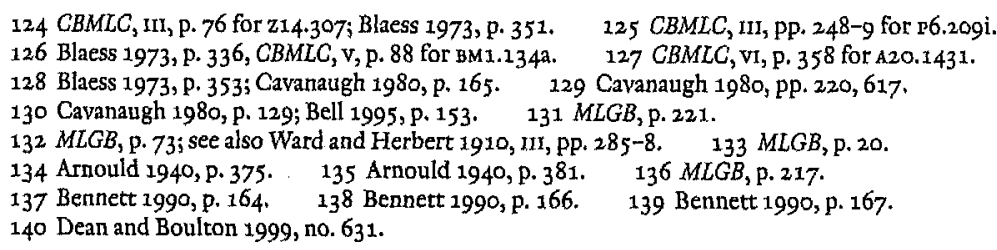


the request of Queen Eleanor of Castile. ${ }^{141}$ Long thought the only manuscript, Paris, Bibliothèque Ste Geneviève, ms. 2899, was written out in 1297 by another Franciscan, Jordan of Kingston, who gave it to his Southampton friary in $1317 .{ }^{142}$ Also containing the Somme le roi and the popular Livre de tribulacion, it is a typical mendicant product, having a 'complete subject-index, with references to the folio and line in Arabic figures'. ${ }^{143}$

Cambridge, Trinity College, ms. R. 14. 7 (fig. 14.4) has already been mentioned. It belonged to Geoffrey de Wroxham, monk of Norwich Cathedral Priory, and contains a compilation traditionally described as a French version of Ancrene wisse. ${ }^{144}$ But the material is so differently though logically disposed that one has to consider that it may contain texts (addressed to both men and women, including lay people) that were sources for, rather than derivatives of, the Middle English text. The compilation has been characterized as 'dualpurpose, designed on one hand to serve as a preparation for confession for laity and religious alike, on the other hand serving as a handbook of advanced religious experience for the initiated'. ${ }^{145}$ The hand is too small for public reading but the dimension of the book $(263 \times 165 \mathrm{~mm})$ make it too large to hold. It would have to be privately studied at a desk.

Not until the mid-fourteenth century do we come across an Anglo-Norman devotional treatise written by a layman: Le livre de seyntz medicines of Henry of Lancaster (c.1310-61). ${ }^{146}$ He wrote this religious allegory of seven wounds infected with the poison of seven sins in $1354 .^{147}$ Although ostensibly addressing God and the Blessed Virgin, the author recognizes a human audience when he asks 'touz ceaux qe cest petit livre litront ou orront lire' to pray for him, and promises to pray for them in return. ${ }^{18}$ The text survives in two manuscripts (there are also extensive fragments in NLW, Peniarth $\mathrm{ms.} 388 \mathrm{c2}$ ). The first, Stonyhurst College, ms. 24 (c.1360), ${ }^{149}$ was given to Duke Humfrey, the author's great-grandson, by Thomas, Baron Carew (d. 1429). The second is Cambridge, Corpus Christi College, ms. 218 (late fourteenth-century)-Henry was regarded as Corpus' founder. Still in its original skin wrapper, it is elegantly restrained, written in brown ink in a small hand, with only one gold initial (most of the initials are in blue with red pen-work). This is in keeping with the author's

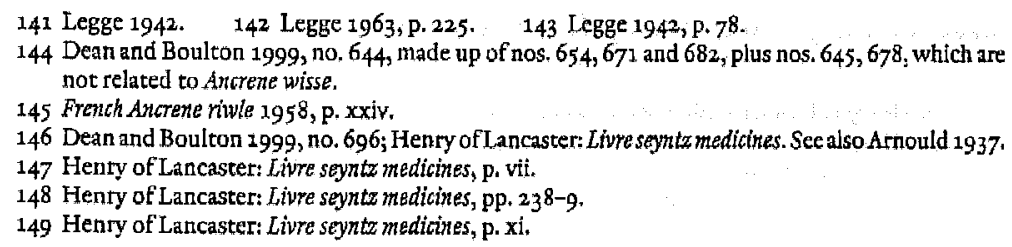


modesty: he apologizes for his inexpert writing and for his French, ${ }^{150}$ describes himself as 'vn fole cheitif peccheour', and conceals his name in an anagram. ${ }^{151}$ In the Middle Ages the Titchfield Premonstratensians owned a $\operatorname{copy}^{152}$ while Maria, Lady Roos and Oreby, bequeathed one in 1394 to Isabella Percy, Henry's step-niece. ${ }^{153}$

But why did Henry choose to write in French, given his qualms? English was well established as a language of religious discourse by the mid-fourteenth century: Ancrene wisse and its associated texts were not unique as works of religious instruction composed in English. Handlyng synne, ${ }^{154}$ the only pre1400 Middle English derivative of the Manuel des péchés, belongs to the early fourteenth century. It is a broad-spectrum work of religious instruction translated by Robert Manning of Brunne, a Lincolnshire Gilbertine canon ( $f l$. 130338). ${ }^{155}$ Although the Gilbertine order did not normally encourage writing, it has been argued that for economic and political reasons they 'had to appeal to "the English" who lived around them. ${ }^{156}$ Robert began his poem as early as 1303 (lines 73-6), writing the preface some time after 1317 . He explains his motivation:

$$
\begin{aligned}
& \text { For lewde men y vndyr-toke } \\
& \text { On englyssh tunge to make pys boke. } \\
& \text { For many ben of swyche manere, } \\
& \text { pat talys and rymys wyl blebely here. } \\
& \text { (lines } 43^{-6} \text { ) }
\end{aligned}
$$

But of the nine complete or partial manuscripts, only Vernon and Simeon (BL, Add. ms. 22283: see further below), which both contain lines 9,899-10,818, entitled 'Septem miracula de corpore Christi', and possibly BL, Harley ms. 1701 (c.1375), are pre-1400. The dearth of earlier manuscripts suggests that the poem, rather than circulating orally (unlikely, given its length), existed in copies that were 'read to death'. Addressed to the common people (ironic, given the luxury nature of the Simeon and Vernon manuscripts), it may have been designed to be read aloud by parish priests to their flock (see lines 10,807-18 and $11,306-10$ ), like the Lay folks' catechism (see further below).

The Ayenbite of inwit by Dan Michael of Northgate $(f l .1340)^{157}$ is the earliest Middle English translation of the Somme le roi, a vast compendium of religious instruction composed c.1280 by the Dominican friar Laurent for Philip III of

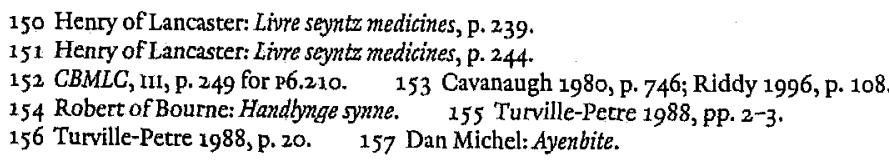


France. ${ }^{158}$ The translator is probably identical with the secular clerk ordained in 1296 to the priory of St Sepulchre, Canterbury (a women's religious house), who by 1340 had become a Benedictine at St Augustine's Abbey, Canterbury. As author (or scribe: the book is ' $y$-write an englis of his ozene hand', f. 2 ) he gave the Abbey the unique manuscript, now BL, ms. Arundel 57, completed in 1340. He also donated twenty-four other books, of a scientific, patristic and didactic nature. ${ }^{159}$

The Ayenbite is another broad-spectrum work of religious instruction, which discusses both marriage and celibacy and covers topics ranging from catechetics to contemplation. It was written for lay folk, 'uor lewede men/Vor uader/and uor moder/and uor oper ken' (II, 262), specifically 'uor englisse men' (II, 5). The size of the manuscript ( $305 \times 195 \mathrm{~mm}$, almost equivalent to modern A4), together with the fair-sized hand and the black ink, suggests that it was not for private reading but for communal or institutional use, perhaps for reference rather than sequential reading given the detailed list of chapters written at the bottom of the first quire's pages. The careful explanation suggests that such an index was unfamiliar, at least to this particular audience:

Pise byeb pe capiteles of pe boc uolzinde / And byepy-wryte to vyndey-redliche / by pe tellynge of algorisme [i.e. Arabic numerals] / ine huyche leave of pe boc pet hy by. And ine huyche half of pe leaue be tuaye lettres of pe abece. pet is to wytene .A. and .b. .A. betocnep pe uerste half of , pe leave .b. pe operhalf.

But we do not know who if anyone actually read the manuscript, which remained in the Abbey until the Dissolution; ${ }^{160}$ there is no evidence for its circulation or influence. ${ }^{161}$

The mid-fourteenth century 16,000-line poem Speculum vitae, traditionally ascribed to William of Nassington (d. 1359), ${ }^{162}$ is 'a re-ordering of material from the Somme le Roi into a grand synthetic double commentary on the Pater noster ${ }^{163}$ Examined by the Chancellor and council of the University of Cambridge in 1384 , only four of its forty surviving manuscripts are pre-1400. These include the Simeon and Vernon manuscripts and CUL, ms. Ll. 1. 8. The latter attributes the poem to Rolle, wrongly giving the date of his death as 1384

158 On the French text and its author see Book of vices, pp. xi-xix

159 Dan Michel: Ayenbite 1979, pp. 12-14. 160 MLGB, p. 57.

161 The book of vices and virtues is another version of the Samme, possibly made c.1375; but of the three copies only the Simeon Manuscript is pre-1400.

162 The Speculum vitae is so far unprinted and unedited in its entirety. The first $37^{\circ}$ ll. were printed by Ullmann 1884 , pp. $468-72$.

163 Gillespie 2989, p. 332 . 
(it also contains a Rolle Passion meditation, which correctly gives the year as 1348). Gillespie characterizes the Speculum, which was intended to be read aloud to those illiterate in French and Latin, ${ }^{164}$ as 'the nearest thing to a vernacular summa produced in the period'. He notes: 'Although probably written for oral performance and for an audience of little theological sophistication, most manuscripts contain an elaborate Latin apparatus ${ }^{3}{ }^{165}$ as does CUL, ms. L1. 1. 8. This suggests clerical mediation, as with Handlynge synne and the Lay folks' catechism.

The most popular poem and the most widely disseminated work of religious instruction written in Middle English, ${ }^{166}$ judging by the 115 known manuscripts, was the anonymous Pricke of conscience (c.1350) (see fig. 6.12). ${ }^{167}$ It consists of 'seven books which describe, in turn, the wretchedness of man's nature, theworld and the various conditions thereof, death and the fear of death, purgatory, the day of judgment, the pains of hell, and the joys of heaven ${ }^{3}{ }^{168}$ all derived from Latin sources, ${ }^{169}$ though the poem itself is not necessarily monastic in origin. ${ }^{170}$ The author explains that his treatise is for 'lewed men' (line 9,601 ), and prays for 'alle pas pat redes it, loud or stille, /Or heres it be red with gode wille' (lines 9,607-8). He also requests their prayers for the translator: 'And yhe pat has herd pis tretice red .... /Pray for hym speciali pat it dru'(lines $9,613,9,616$ ).

The work of Lewis and McIntosh on the manuscripts supports a recent pronouncement that the Pricke of conscience' seems to have had the same patterns of ownership among the middle ranks of clergy and gentry as ... the Speculum Vitae ${ }^{3}{ }^{171}$ The Arundel Castle manuscript (late fourteenth-century) belonged to the York Franciscans; CUL, ms. Dd. 12.69 (late fourteenth-century), was given to Shermanbury parish church (Sussex) by John Haynes in the early fifteenth century; Cambridge MA, Houghton Library ms. English 515 (second half of the fourteenth century) belonged to a John Kyng in the fifteenth century; the Simeon Manuscript may have belonged to Joan Bohun (d. 1419), Countess of Hereford, mother-in-law of Thomas of Woodstock and Henry IV..$^{172}$ BL, Add. ms. 24203 (late fourteenth-century) was written by a Cistercian monk of Fountains Abbey: this single-item, functional, codex has a simple decorative scheme and would be a good size $(205 \times 155 \mathrm{~mm})$ for reading aloud. Bodleian, $\mathrm{ms}$. Digby 99 (late fourteenth-century), belonged to a canon at the Cluniac priory

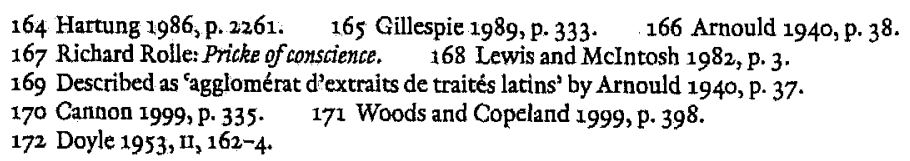


at Thetford but later to lay men and women. It contains Norwich synodalia and several other catechetical texts in Middle English, introduced (f. 25 ) by a ten-line Latin rubric listing what a parish priest is duty-bound to preach. The Vernon Manuscript may have originated from the Cistercian abbey of Bordesley; ${ }^{173}$ Bodleian, ms. Rawl. poet. 175 (second half of the fourteenth century) contains 'the name "Thomas Gyll', who may have been a chantry priestsomewhere in Yorkshire in the early fifteenth century; ${ }^{374}$ Princeton, UL, Taylor ms. Medieval 13, (second half of the fourteenth century) belonged to John Aston of Cropwell Butler, Nottinghamshire; ${ }^{175}$ Dublin, Trinity College, ms. 69 (A.4.4) (fourteenth/fifteenth-century) was 'probably of ecclesiastical origin, though it belonged to a layman later in the fifteenth century'. ${ }^{776}$

Of the pre-1400 manuscripts with early provenance information, then, one belonged to Franciscans, two or three to Cistercians, one to a Cluniac house, three to lay men, two to secular priests, and one (possibly) to an aristocratic lay woman. Clearly the text had wide appeal among men and women, clergy and laity. Medieval wills provide further information. In 1399 Thomas Roos of Ingmanthorp, Yorks, bequeathed a copy to William de Helagh; ;77 $^{17} 1415$ Henry le Scrope, Lord of Masham, bequeathed one to his sister Matilda, a London Minoress. ${ }^{178}$ There are four further bequests (two by lay men, two by clerics) in the fifteenth century, possibly of later copies.

Nearly contemporaneous is the mistitled Lay folks' catechism, ${ }^{179}$ composed in 1357 by John Gaytrygge (or Gaytryk), a Benedictine monk of St Mary's Abbey, York. Archbishop Thoresby had commanded him to translate the Creed, the Ten Commandments, the Articles of the Faith 'and other things' into the vernacular for the instruction of the laity, ${ }^{180}$ an expansion of his directions to the York clergy, in their turn modelled on Pecham's 1281 Lambeth Constitutions. Although characterized by Hudson as a 'relatively late and unsophisticated product of the educational movement whose aims were formalized in the edicts of the 1215 Lateran Council', ${ }^{181}$ Gillespie comments that Thoresby's instructions ' mark a significant stage in the evolution of the vernacular pastoral manual by conferring official approval on and encouraging the circulation of a vernacular version of his Latin original'. ${ }^{182}$

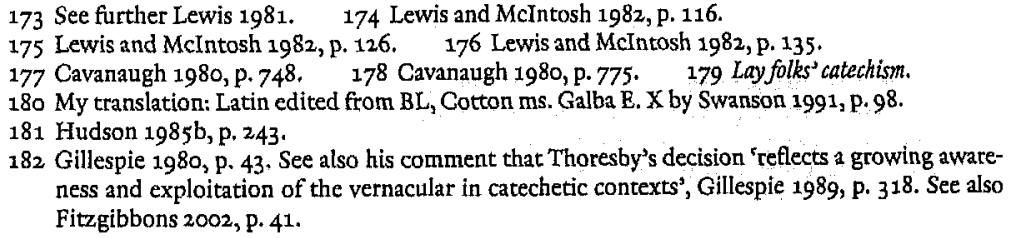


Few of the twenty-six manuscripts containing complete or partial versions of this text ${ }^{18_{3}}$ pre-date 1400 , although BL, Add. ms. 24202 , and BL, ms. Arundel 507 (which belonged to Richard of Segbrok, monk of Durham Cathedral Priory, fl. 1396), are dated as c.1400. But the text circulated in other ways: in 1.401 Richard Ullerston claimed that Thoresby had sent copies 'in smale pagynes to pe comyn puple', ${ }^{184}$ and the Archbishop's Register preserved the English text along with the Latin. Ian Doyle states that this copy 'can be dated firmly to 1357 and its scribe named ${ }^{185}$ and points out:

The other early copies... are all northern ... though notbefore the last quarter of the century, and of utilitarian character... . Since any separate 'pamflet' copies made for its original pastoral purpose were unlikely to last independently ... the Catechism survives almost solely within volumes containing other texts of English and Latin catechetic, homiletic, ascetical and meditative literature, compiled as much for private reading as public use. ${ }^{186}$

The peculiarities of circulation are bound up with the unusual nature of this text, which was composed as a script for oral performance by the clergy: the archbishop

$$
\begin{aligned}
& \text { Has tretyd and ordayned for commune profet, } \\
& \text { Thurgh the consaile of his clergie. } \\
& \text { That ilkane that vndir him has kepynge of saules, } \\
& \text { Openly on Inglis opon sononndaies } \\
& \text { Teche and preche thaim, that thai haue cure of, } \\
& \text { The lawe and the lore to knawe god all-mighten.... } \\
& \text { (lines } 46-51 \text { ) }
\end{aligned}
$$

It was therefore written in English for the benefit of uneducated priests, not of the laity. Similarly, copies were originally owned by priests: 'Almost all the surviving copies . . . indicate that the clergy were ordinarily the owners and users, the laity merely listeners' ${ }^{187}$ although '[1]ater in the fourteenth and throughout the fifteenth centuries its use was extended to both private reading and public recitation'. ${ }^{188}$ So here we have an interesting example of a text that is not $a$ book, or even in a book, until the early fifteenth century when it becomes, as it were, privatized and personalized, as in the Thornton Manuscript. $^{189}$

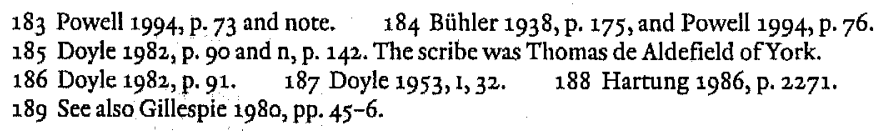


Although Richard Rolle died in 1349, there are very few pre-1400 copies of his works. Hope Emily Allen remarked that this 'probably should be interpreted as meaning that the first copies were worn out by the eagerness of readers'. ${ }^{190}$ But this phenomenon is not peculiar to Rolle, and Michael Sargent has noted the paradox that 'the fifteenth and early sixteenth centuries were the great age of thirteenth and fourteenth-century spirituality'. ${ }^{191}$ Perhaps, though, rather than puzzling over the scarcity of fourteenth-century copies of Rolle'swritings, we should emphasize their relative popularity in the fifteenth century when Archbishop Arundel's Constitutions had discouraged the circulation of later, possibly heretical, vernacular texts. ${ }^{192}$

The earliest dated Rolle manuscript is BL, Add. ms. 34763 , a small commonplace book $(160 \times 110 \mathrm{~mm})$ written in a number of different hands: on f. $44 \mathrm{~V}$ Rolle's Emendatio vitae is dated to 6 April 1384 . The contents, exclusively Latin and including the pseudo-Bernardine Speculum peccatoris and the Scala claustralium, suggest ownership by a male cleric with contemplative interests, while the size suggests private study and devotion.

Early copies of Rolle's Incendium amoris ${ }^{193}$ include CUL, ms. Dd. 5. 64 (see below: it contains both Latin and English texts); Brussels, Bibliothèque royale, mss 21.03 and 1485 (also containing the Oleum effusum), both of which belonged to the Enghien Charterhouse in Hainault; ${ }^{194}$ and Uppsala, University Library, ms. c. 1 , which belonged to the Bridgettine mother house in Vadstena. Christopher Braystones (d. 1374 or 1375), Benedictine monk of St Mary's, York, owned a manuscript containing this text and the Emendatio vitae, ${ }^{195}$ while in 1415 Henry le Scrope bequeathed a copy of the Incendium (and another containing Judica me). .196

The Emendatio survives in over ninety manuscripts. Pre-1400 copies (apart from BL, ms. Add. 34763) include CUL, ms. Dd. 5. 64, and Bodleian, ms. Hatton 26. Section $C$ of this manuscript, which contains the Rolle text (and also the original Latin text of Edmund of Abingdon's Speculum), belonged to the Stafford Priory of Augustinian canons, an order which often had parochial responsibilities and might well use vernacular material. Its scribe also wrote ms. Hatton 86 (see below). In 1427 John Newton, rector of Houghton-le-Spring, bequeathed a copy ${ }^{197}$ while the London Carmelites owned a manuscript containing the Emendatio, the Incendium and other Rolle texts. ${ }^{198}$

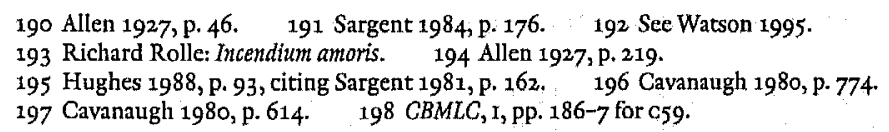


Rolle's commentaries on Canticles are found in Oxford, Corpus Christi College, ms. 193 (late fourteenth/early fifteenth-century), which belonged to John Hanton, monk of St Mary's Abbey, York; ${ }^{199}$ in Hereford Cathedral Library ms. o. vIII. (late fourteenth-century), which belonged, at least in the next century, to Hereford Cathedral and contains eight other Rolle texts; and Brussels, Bibliothèque royale, ms. 1485 (see above).

The Melos amoris ${ }^{200}$ is found in BL, Sloane ms. 2275 (late fourteenth/early fifteenth-century, $240 \times 170 \mathrm{~mm}$ ), which also contains the Incendium, Emendatio, Job and Contra amatores mundi as well as the Middle English poem Stimulus conscientiae (written as prose), and Edmund of Abingdon's Speculum, addressed to male religious. In spite of its large size it lacks the easy legibility desirable for public reading. Uppsala, UL, ms. c. I (mentioned above) contains the Melos and the Incendium and belonged to Vadstena.

The Expositio in Job, 'strictly speaking, a liturgical not a Scriptural commentary', ${ }^{201}$ survives in forty-four manuscripts. In it Rolle 'encouraged the pursuit by the clergy of a rigour of religious life which hitherto had been the prerogative of the cloister. .. In literary terms his work encouraged the movement of the pastoral manual into the realm of the contemplative treatise, to meet (while at the same time encouraging) these new expectations. ${ }^{202}$ It is found in $\mathrm{BL}$, Cotton ms. Tiberius A. XV, ff. 181-94 (formerly part of Oxford, Corpus Christi College ms. 193), owned by St Mary's, York; Bodleian, ms. Hatton 86, which belonged to the Augustinian priory at Stafford (see above); and Oxford, Magdalen College, ms. Lat. 6, which belonged to John Martell (fl. 1420), fellow of Oriel. Of Rolle's other scriptural commentaries, Lambeth, ms. 352, was given to Master John May, rector of All Saints, London, by Robert Norton, chaplain of the abbey of Benedictine nuns at Malling (Kent), ${ }^{203}$ while Paris, BnF, ms. lat. 431, belonged in the next century to Jean d'Angoulême. The text appears quite frequently in later medieval clerical wills from the diocese of York: 'whilst never as widely owned as William of Pagula's Pars Oculi and John of Burgh's Pupilla Oculi, [it] appears in bequests in comparable numbers to the Legenda Aurea and Summa Summarum'. ${ }^{204}$

In contrast to his Latin texts, many of Rolle's English works were written for women, such as Margaret Kirkeby, 'and for other unlettered [in the sense of not knowing Latin] Christians'. ${ }^{205}$ On this subject CUL, ms. Dd. 5. 64, is particularly well-informed. It contains the Latin Emendatio vitae, Incendium amoris and Exposicio oracionis dominicae; the English Form of living ('scripta a beato

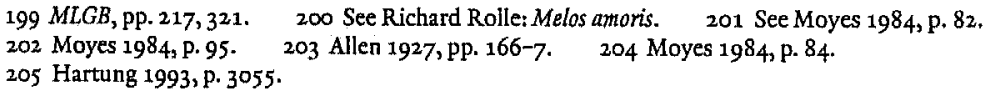


Ricardo heremita ad Margaretam anachoritam suam dilectam discipulam'); Ego dormio ('scriptus cuidam moniali de 3 edyngham'); Commandment of love ('scriptus cuidam sorori de hampole'); ten poems; and a fragment of Three wyrkings. Made up of three sections (all defective at the end), Sections $A$ and $C$ are late fourteenth-century. The inclusion of Latin texts, and the use of Latin in the rubrics to the English texts, suggests a male clerical audience and/or ownership, possibly by a cleric with charge of women religious.

Pre-1400 manuscripts of Rolle's Meditations on the Passion, 'directed toward beginners in the life of prayer', ${ }^{206}$ include CUL, ms. Ll. 1.8 (c. 1350-1400), which also contains the Speculum vitae (attributed to Rolle), and the Vernon and Simeon Manuscripts. The meditations are related to (possibly even translated from) an Anglo-Norman text in CUL, ms. Ee. 6.16, which belonged to a house of nuns of the order of Fontevrault, probably Amesbury: it contains a prayer to Fontevrault's founder, Robert of Arbrissel. Much of the contents is in Latin, with feminine forms such as 'anime famule tue'. But surprisingly, the grammatical forms in the Anglo-Norman text are masculine, such as 'tous ceux ... vifs et mors'.

The Vernon and Simeon Manuscripts also contain copies of Ego dormio, the Form of living, The bee and the Ten commandments. The latter occurs in Bodleian, ms. Hatton 12 (f. 1 has a chronological note dated 1386), which contains the English Psalter and the Magnificat: it is a big book $(355 \times 240 \mathrm{~mm})$ ideal for public reading, the Latin verses of the Psalms written eye-catchingly in red, with blue capitals.

In conclusion, early Rolle manuscripts (both English and Latin) belonged to various monastic orders, in England and on the Continent - Carthusians (two), Augustinian canons (three), Bridgettines, York Benedictines (two); a cathedral; an individual priest (John May) - but not apparently to mendicants. Wills mention some unspecified Rolle texts. In 1391 Sir William de Thorpe of Northamptonshire left his chaplain 'that book which Richard Heremit composed', ${ }^{207}$ an interesting example of transfer from lay to clerical ownership. Richard Sotheworth, rector of South Morton (Berks), who died in 1419, left 'a certain book of mine of Richard the Hermit'. ${ }^{208}$ In 1432 Robert Semer of York left 'librum meum de Placebo et dirige, secundum Ricardum heremitam, cum aliis libris ejusdem contentis in eadem' to Robert Helperby, vicar. ${ }^{209}$ But in spite of Rolle's decision to write for religious women in English, there is no evidence before 1400 that such women actually owned these texts.

206 Hartung 1993, p. 3057. 207 Allen 1927, p. 413; Cavanaugh 1980, p. 862. 208 Cavanaugh 1980, p. $798 . \quad 209$ Cavanaugh 1980, p. 780. 
Walter Hilton died in March $1395 / 6$, so it is less surprising that so few pre1400 copies of his works are extant. The date ' 1394 ' is written in Bodleian, ms. Rawl. c. 285, which contains The Scale of perfection Books I and II, Pricke of love, Form of living and an extract from Catherine of Siena; but the Arabic numbers are post-medieval and the manuscript clearly after 1400 . The Vernon and Simeon Manuscripts do contain a number of Hilton texts, including Scale I, Mixed life and Pricke of love. Further evidence for the circulation of the The Scale around the year 1400 is provided by the Carmelite John Pole (fl. 1380), who commissioned a copy, now York, Cathedral Chapter Library, ms. xvI. K. 5,210 of the Latin translation of The Scale made by his fellow Carmelite Thomas Fishlake 'probably as early as 1400 or before'. ${ }^{211}$ In 1414 John Newton, Master of Peterhouse and subsequently treasurer of York, bequeathed to the chapter of York Cathedral books by Hilton (and John Howden and Rolle among others); ${ }^{212}$ while in 1432 Robert Wolveden, treasurer of York, bequeathed 'unum librum devotum factum per Walterum Hilton', ${ }^{213}$ and in 1438 Eleanor Roos of York bequeathed 'unum librum Anglicum vocatum librum primum Magistri Walteri' to a relative. ${ }^{214}$ All these might well have been pre-1400 copies.

The Cloud-author and his works are even more elusive. He may have been writing at the end of the fourteenth century but there is no pre-1400 manuscript of the complete text of the Cloud or Denis hid divinity, though Cambridge, Corpus Christi College, ms. 385,pp. 213-20 (c.140o), contains a copy of Benjamin minor, written in a tiny hand. Indeed, Gillespie suggests that widespread dissemination of his writings was deliberately prevented, as the author had wished. ${ }^{215}$

The Vernon and Simeon Manuscripts, now dated c.1380-1400, come right at the end of our period. ${ }^{216}$ They have one scribe in common, their contents largely overlap, and they are clearly related. Though the defective nature of Simeon (which may be slightly later than Vernon) makes the exact relationship hard to establish, Doyle characterizes the two manuscripts as parallel products, 'for the greater part, yet notentirely'. ${ }^{217}$ Simeon omits Vernon's version of Ancrene wisse and adds both the Book of vices and virtues and part of Sir John Clanvowe's The two ways: this might suggest that the compilation was designed for a lay man rather than a devout woman (lay or religious), ${ }^{218}$ but it has long been maintained,

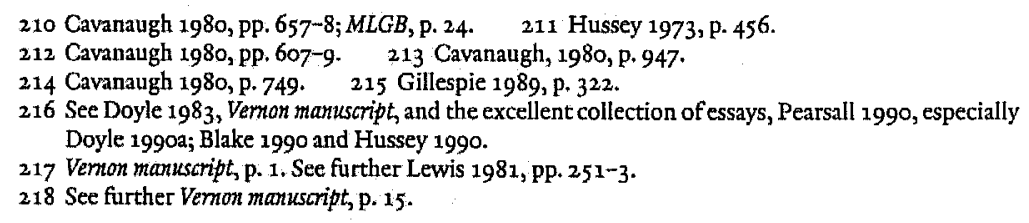


perhaps on rather insecure grounds, that Simeon belonged to Joan Bohun (see above, p. $35^{8}$ ). But whoever commissioned or owned the manuscript must have been of high status: the manuscript is extensively decorated, even if the decoration is garish and not always well executed.

Vernon contains, mainly in Part IV, an extensive butdiscriminating collection of works of religious instruction. ${ }^{219}$ These include no fewer than three English versions of Edmund of Abingdon's Speculum and one of Grosseteste's Chasteau; the earliest copies of Abbey of the Holy Ghost and the Charter; Hilton and Rolle texts; the Stimulus amoris; Ancrene wisse, and A talking of the love of God. Of some of the minor pieces these are the earliest copies, even though Vernon does not often provide 'good' versions of the more important texts. No doubt texts which perished elsewhere in more ephemeral form survived in Vernon because of the manuscript's bulk and extraordinary value. It would be a hard book to mislay. The volume is carefully planned and Gillespie comments on the functionality of the index, probably added rightat the end, which 'allows access to sections of works containing matter of particular interest to a particular reader at a particular time, permitting the manuscript to be read thematically. In a sense, it becomes a spiritual encyclopaedia. ${ }^{1220}$

Scholars have speculated for years about the Vernon Manuscript. Many fascinating questions have been posed, but no indisputable answers provided. As Ian Doyle has said, 'as for the initiators, patrons, compilers, original purposes and eventual owners, we ... are forced still to speculate'. ${ }^{221}$ Opinion is divided as to whether the volume was compiled for lay people (an armigerous family, perhaps?) or for religious (women, or perhaps lay brothers?). Many of the texts seem to have been chosen to appeal to devout women but it would be hard to tell from internal evidence alone if this female audience were lay, religious, or in-between (say, a community of vowesses or up-market quasi-beguines), for 'the literary culture of nuns in the late fourteenth and fifteenth centuries and that of devout gentlewomen not only overlapped but were more or less indistinguishable ${ }^{2222}$

It is peculiarly frustrating to have to end on this note of uncertainty, for one cannot overestimate the significance of this manuscript. Although any reader's first and abiding impression is of 'a huge book intended for public reading and display', Vernon is more than a monument to the spread of

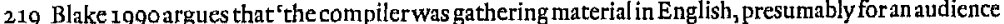
which was either unfamiliar with, or not very confident in the command of, Latin and French' (p. 46) and characterizes Vernon as 'a complete Christian book for someone not in holy orders' (p. 57 ).

220 Gillespie 1989 , p. 328. $\quad 221$ Vemon manuscript, p. $14 . \quad 222$ Riddy 1996, p. 110.
} 
Readership, libraries, texts and contexts

literacy (from male clerics to lay folk and women), and of English (supplementing rather than entirely replacing Anglo-Norman and Latin as a language of religious discourse). It is also still 'part of a predominantly oral and memorialising culture':223 that is, of a firmly medieval culture, blissfully unaware that printing, and print culture, were just around the corner.

223 Riddy 1996, p. 111 